\title{
Unfulfilled Loan Demand among Agro SMEs in Namibia
}

\author{
Elina Amadhila and Sylvanus Ikhide \\ University of Stellenbosch Business School \\ Accepted: January 2016
}

\begin{abstract}
Using a qualitative methodology approach, a case study research design by way of in-depth semi-structured interview(s) was followed to interview farmers, commercial banks, development banks, venture capitals and private equities to determine the financing options available for farmers and provide reasons why some financial institutions shy away from providing finance to agricultural enterprises. This study deviates from prior studies which have focused on small-scale farmers and subjected farmers' access to finance to rural credit markets, mostly informal money lenders using secondary information mostly from household surveys to build econometric models. The study indicates that only about 33 percent of formal financial institutions are providing finance to agricultural SMEs. The lack of expertise and perception of risk were cited as top reasons why formal financial institutions find it hard to provide finance to agricultural SMEs. Building on opinions from other authors cited in this paper, we maintain that new financing mechanisms can be achieved by all types of financial institutions through learning from experiences by other successful countries.
\end{abstract}

Key words: financing options, farmers, Namibia, agriculture

JEL: M13, Q13, 14

\section{$1 \quad$ Introduction}

Although the latest assessment of Namibia's financial system stability by the International Monetary Fund (IMF) concluded that the banking sector is mature, very profitable and wellcapitalised (International Monetary Fund, 2007; Bank of Namibia \& Namibia Financial Institutions Supervisory Authority, 2015), recent evidence shows that farmers are unaware of any financing options open to them (Schutte, 2015). This lack of information and low productivity in agriculture suggest an opportunity for agricultural development (Ministry of Agriculture Water and Forestry, 2008). Among the many factors that could lead to agricultural development, access to finance for Agricultural Small and Medium-scale (SMEs) farmers is considered important (Norton, Alwang \& Masters, 2015).

The motivation for this paper follows the argument by Siebel, Giehler and Karduck (2005:13), who maintain that there are two issues affecting the demand and the supply-side of financial resources. These are the lack, on the one hand, and the abundance, on the other, of financial resources, both resulting paradoxically in a lack of resources for agricultural investments. On the side of the lack of financial resources, there is evidence that the number of donor-supported agricultural investments is in decline and there is not much to show that government or commercial finance are compensating for the reduction in the supply of loanable funds to agricultural production. When it comes to financial resources, there is an abundance of loanable funds in rural institutions, because there are more savers than there are borrowers, which results in excess liquidity. Although the excess liquidity is generated in rural areas, it is siphoned off to urban areas. In this paper we aim to examine the financing options for agricultural SMEs in order to identify and understand the lack or abundance of financial resources in Namibian agriculture. The importance of studying the access to finance for agricultural SMEs in Namibia cannot be over-emphasised, as agriculture contributes to food security, food sovereignty, and the national culture in Namibia, so access to finance for agricultural SMEs is crucial to fighting poverty. The findings of this research give important information and advice, which could be immensely valuable to farmers, bank personnel, investors and planners in agricultural development and decision-makers at any level in terms of access to finance. 
There is evidence that the analysis and documentation of literature in agricultural credit, particularly in Namibia, are lacking and this paper aims to fill the gap. Tonin, Dieci, Ricoveri, Foresi and Hansohm (1998:11) conducted a study focusing on financial services for small enterprises in Namibia but their paper excluded agricultural enterprises because of their "unique nature". Other studies elsewhere that focused on small-scale farmers have subjected farmers' access to finance to rural credit markets i.e. informal money lenders using either econometric models or secondary information to analyse the data (see Hoff \& Stiglitz, 1990; Aleem, 1990; Obeng, 2008). To our knowledge, there has been no such study in Namibia and there is a need for greater specificity. This paper focuses on both the formal financial institutions (supply-side) and agricultural SMEs (demand-side), using a naturalistic approach with primary data. Although previous literature already provides us with information on credit access for agricultural SMEs, this information is very slight (Cabannes, 2012) and does not allow us to grasp the real issues to enhance our understanding. This explains why this paper focuses on narratives that highlight and illustrate key issues. For the purpose of this study, the type of farmers that are the subject of discussion here are the small- and medium-scale famers rather than subsistence farmers (who barely interact with the market) or large farmers (who are generally well financed). This paper intends to explore the following two objectives:

1) To identify the financing options for agricultural SMEs from both the demand and the supplyperspectives.

2) To identify reasons why formal financial institutions may not be involved in agricultural finance in Namibia.

The rest of the paper is structured as follows: the next section considers the theoretical framework and the literature review; section 3 provides information on Namibia's banking institutions; the methodology is explained in section 4, while section 5 presents the results of the study. Section 6 discusses the results and implications of the study, and section 7 concludes.

\section{Theoretical framework and literature review}

\subsection{Theory}

Until the early 1980s, agricultural planners in developing countries were concerned with the need to increase food production. As a result, vast amounts of financial resources were poured into agricultural development banks until the donors withdrew them in the early 1990s because the banks 'performance was measured in terms of loan disbursements rather than the actual number of small-farmer borrowers. As a result, the development banks were tempted to grant loans to well-established larger farmers rather than small-farmer borrowers and therefore missed their target group (Klein, Meyer, Hannig, Burnett, \& Fiebig, 1999). The absence or withdrawal by development banks from lending to small famer-borrowers has also not allowed the private supply of funds to rural areas, as the private sector's service tends to target the wealthier sectors. In other words, neither the countries whose donors withdrew their support from development banks nor those that changed the banks' approach to private-sector financing managed to achieve a widespread service to agricultural clients. Apart from the private-sector microfinance institutions that were set up after the unsuccessful operation for agricultural development, banks have not managed to close the agricultural finance gap, either because they focused more on financing small-scale trading activities in urban areas, paying little attention to the rural population involved in agricultural production (Siebel et al., 2005). The Namibia Financial Institutions Supervisory Authority (NAMFISA) has revealed that micro-lenders serve only the formally-employed sector, i.e. lending by these institutions is salary backed. ${ }^{1}$ Trivelli and Venero (2007) posit that the reason for the limited response from the private sector lies in the failure of the rural financial markets.

Given this, the theoretical framework guiding this study is the failure of the market to allocate resources efficiently or fairly. Jensen (2000) argues that market failures in agriculture exist, which could have been caused by monopoly power on the part of agricultural lenders, possible 
information asymmetries (generally referred to as insufficient information held by the lender regarding the borrower) and incorrect perceptions of agricultural risk from the standpoint of agricultural lenders. The existence of market failures in agricultural markets results in inefficient markets and less credit given to agricultural borrowers.

Trivelli \& Venero (2007), however, maintain that, despite the failure of the rural financial markets, agricultural SMEs could (and should) be served by development banks, as this could result in significant gains for the economy by, for example, reducing poverty. Given this theory, this study explores whether formal financial institutions in Namibia are involved in financing agriculture and, if not, for what reasons? A review of the financing options that could be used or are being used to finance agriculture is presented in the next section, followed by a review of the reasons why financial institutions do not provide finance for agriculture.

\subsection{Literature review}

The literature review section is divided into three sub-sections: Financing options and lending techniques, reasons for not financing agriculture and stylised facts on Namibia's financial sector. Agricultural SME finance ${ }^{2}$ is defined as financial services for small and medium enterprises engaged in agricultural production (i.e. farming) and production-related activities, such as input supply, processing, trade, wholesaling, and marketing (International Finance Corporation, 2011:13).

\subsubsection{Studies with financing options and lending techniques suggested}

\section{Financing options}

The major sources of finance can be classified as debt and equity. Debt is referred to as outside finance (formal and informal), while equity is the owner's investment in the business in the form of capital (Akingunola, 2011). Trzeciak-Duval (2003) suggests that one of the options for developing financial infrastructure and bank restructuring is for commercial banks to establish specialised rural financing units in order to provide debt, although this may create tension between the pure profit maximisation objective and the need to service agriculture and the rural areas. However, complementary instruments like guarantee schemes could be introduced. This means that an increase in rural financing institutions is one way of promoting awareness of the formal sources of help available for farmers. Trivelli and Venero (2007:29) maintain that, in Latin America, for example, financial entities have developed innovative technologies for gathering local information, established credit bureaux to store customer's credit histories and share them among financial entities, benefiting both the financial market and the customers.

In Bangladesh, as another example, out of five Development financial institutions, only two were active lenders to agriculture. The government in Bangladesh provides refinance facilities to financial institutions interested in financing agriculture. These refinance facilities are provided for three types of loan products: short-term loans to cultivate crops, medium-term loans for livestock and poultry production and long-term loans for agricultural equipment. Although these banks in Bangladesh later became insolvent because of growing capital deficits, reformation took place later (World Bank, 2008a).

Coates and Hofmeister (2012:85) suggest that innovative approaches to increasing financial services to more isolated rural areas involve branchless banking but such approaches should not substitute a branch network because nothing seems to capture the full financial services of a community like a "bricks and mortar" branch.

\section{Lending techniques}

Closely linked with the debate on financing options/mechanisms for agriculture is the discussion on lending techniques. Huppi and Feder (1990) note two lending techniques, the main forms being group and individual lending. Huppi and Feder (1990) further note that there are notable successes for group lending for financial institutions, for example, reliance on members' deposits rather than 
on outside sources for funding. Kodongo and Kendi (2013) support Huppi and Feder (1990) by arguing that group lending helps individuals to be more financially stable and reduces the risk of default because of pressure from other members of the group to pay on time (see also Besley \& Coate, 1995).

On the contrary, Lehner (2009) suggests that group lending may be regarded as ineffective when the costs of monitoring for the group members are high because of loose social ties. This might have a negative effect on repayment, as the incentive of future credit is no longer present if one member fails to pay. Lehner (2009) therefore concludes that individual lending may be preferred when the requested amount is small, refinancing costs are low and competition is intense. Presenting a basic model and comparing between the optimal individual lending contract and the optimal simple group lending, Bhole and Ogden (2010) disagree with Lehner (2009). They argue that group lending performs better than individual lending, even in the absence of social sanctions.

Kodongo and Kendi (2013) conclude that the choice between individual and group lending should be informed by each financial institution's philosophical orientation, because high default from either individuals or groups is attributed to the failure by loan officers to properly screen, encourage and train clients on financial discipline.

Our view is that lending institutions' expertise on agricultural financing is important for the implementation of either individual or group lending.

Although financing options are suggested in successful countries, such as Bangladesh and Latin America, in countries such as Nigeria, banks are ready to give a sizeable proportion of credit to SMEs only if they are forced to do so. This was observed when the mandatory commercial bank's credit allocations of 20 per cent of the total credit to small scale enterprises declined progressively after it was abolished by the government through the Central Bank of Nigeria (Olutunla \& Obamuyi, 2008).

\subsubsection{Studies on why financial institutions do not give finance to agriculture}

Coates and Hofmeister (2012) argue that, in most parts of the world, agriculture is exposed to high systemic and market risks, which, as a result, has created the problem of the lack of access to finance for Agricultural SMEs and has hampered their performance and productivity. Apart from being regarded as risky, other reasons cited as to why financial institutions are reluctant to provide finance to agricultural SMEs are:

- Agricultural SMEs lack skills (Namibia Training Authority, 2013);

- the existence of information asymmetry arising from inadequate financial statements, making it difficult to assess their effectiveness; and

- the high administrative or transactional costs of lending and investing small amounts (Abereijo \& Fayomi, 2005, cited in Akingunola, 2011).

Jayasinghe (2009) conducted a survey in Gampaha (Sri Lanka) on 22 financial institutions and only 10 of which were involved in agricultural ventures. Among the many perceived or practical bottlenecks in financing agriculture are concerns about farmers' behaviour when it comes to repayments; the perception that urban agriculture is small and unprofitable or does not match the current strategic objectives of the institution, to name but two. The World Bank (2008a) pointed out that the challenges faced by banks in serving small- and medium-scale farmers are training loan officers and appraising agricultural activities, developing products with flexible repayment schedules that fit agricultural cycles, coping with weather risks, developing delivery and monitoring mechanisms that keep costs low, while serving sparsely-populated areas. Further, Siebel, Giehler and Karduck (2005) note that almost no use is made of commercial banks by small farmers in tropical Africa and elsewhere, because there are few branches of private banks in rural areas, and banks are reluctant to lend to small farmers without title to land (Mollett, 1984). Jessop, Boubacar, Marjan, Abdallah, Job and Bert (2012) reason that the heavily-subsidized interest rates usually place a low ceiling on savings deposits, so that the system discourages commercial banks 
from lending to farmers. For this reason, most banks have neither the rural branch networks nor the agricultural lending expertise which would enable them to serve small farmer clients.

Coates and Hofmeister (2012) extend their discussion to Venture capital funds, arguing that, when it comes to Venture Capitals (VCs) and Private Equities (PEs), the attention received by SMEs, particularly in the agricultural sector, as opposed to other sectors in Africa, is not much because of the paucity of information in the agricultural sector, and because the potential investor's understanding is limited. This is not to forget the restrictions the investors place on venture capitals (see also Samsel, Hambley \& Marquardt, 1991).

The agricultural sector is undeniably unique and faces greater risks than other sectors do when it comes to financing, but every business, irrespective of the sector in which it falls faces risks to a certain extent. The question to ask is: How are those risks mitigated in other sectors? How could they be adjusted not only to serve an agricultural entrepreneur but also to satisfy the financier? Hartig, Jainzik and Pfeiffer (2014) suggest that structured finance may be the way to go in agriculture. Structured finance refers to the advancement of funds to enterprises to finance inputs, production and the accompanying support operations using certain types of security that are not normally accepted by banks or investors and which are more dependent on the structure and performance of the transaction, rather than on the characteristics of the borrower. Therefore in agricultural finance there is a tendency to focus on securities (i.e. collateral) in order to reduce credit risk, rather than focusing on other aspects like risk transfer or liquidity. Structured finance can for example take the form of, inter alia, contract farming, agricultural portfolio guarantees, warehouse receipt finance and forward contracts.

\section{Stylized facts on Namibia's financial sector}

\section{Development Banks}

Development Banks (AgDBs) are defined as mainly government owned institutions (Siebel et al., 2005). In Namibia, there are two development banks, the Development Bank of Namibia (DBN) which started in 2004 and the Agricultural Bank of Namibia (Agribank), which started as far back as 1907. DBN was set up with the aim of contributing to national economic development by financing various types of economic enterprises, projects and activities. It provides finance for both the public and the private sectors (including emerging entrepreneurs and SMEs) for start-ups and expansions, equity deals, bridging finance, enterprise development finance, trade finance, small and medium enterprises finance, public private partnerships, public sector infrastructure, local authorities and bulk finance to microfinance providers (mainly term-lending credit only micro lenders) (Development Bank of Namibia, 2014). Agribank, on the other hand, provides loans for agriculture and fisheries-related economic activities, including small-scale famers. In order to boost food security, the government of the Republic of Namibia diverts certain funds to agricultural activities according to the principle of contract farming in its Green-scheme Policy of 2003. The ministry has appointed Agribank to make production and capital loan facilities available to farmers in the green-schemes. ${ }^{3}$

The International Monetary Fund (IMF) (2007) has revealed that only 9.5 per cent of lending is allocated to agriculture, forestry and fishing, relative to the total credit from commercial and development banks in Namibia (International Monetary Fund, 2007). Nevertheless, Agribank continues to be the major credit-provider for agriculture. Agribank was promulgated in order to expand the scope of business to capitalize on opportunities in the market and transform the institution into a more versatile institution, responsive to all the stakeholders in order to meet the demands of the ever-changing business environment (Agribank, 2014). Agribank continues to receive the greatest portion of financial support from government, with $\mathrm{N} \$ 321$ million expected for the financial year 2015/16 (Menges, 2015). The number of loans to agriculture from Agribank has increased over the years from N\$1.063 282 million in 2003 to N\$1.930 667 million in 2015 (Abiatar, 2015). Despite this increase, lending to farmers remains a challenge, because of the 
mortgage collateral requirements that are quite restrictive, especially to small-scale farmers in communal rural areas. This is exacerbated by the lack of secured land rights to enable access to credit by the majority of small-scale farmers in rural areas to expand and develop agricultural land to its full potential (see Ndjoze, 2012).

\section{Commercial banks}

Commercial banks are defined as banks falling under the banking law and not under a special act, such as the Development Banks Act or the Agricultural Reform Act (Seibel et al., 2005:17). In Namibia, the banking industry comprises six commercial banks, four of which are traditional commercial banking institutions (the First National Bank of Namibia (FNB), the Standard Bank of Namibia, NedBank of Namibia and Bank Windhoek), while two are specialised banking institutions (i.e. FIDES Bank, which is a microfinance deposit-taking bank and the SME Bank). Bank Windhoek is the only locally-owned bank, while other commercial banks are subsidiaries of foreign institutions. According to Kaakaunga, Zaaruka, Motinga and Steytler (2004), the distribution of commercial banks in Namibia is heavily skewed, in favour of urban centres, with only a few branches located in rural areas. Although lending to agriculture from commercial banks has been increasing over the last 15 years in Namibia, it has moved at a very slow pace from 2001 to 2011, and dramatically increased from the year 2011 to the year 2014 (Abiatar, 2015). See Table 1 below. It is unclear whether these lendings went to large farmers, medium or small farmers. Other research has shown that, although commercial banks do finance agriculture, this type of finance usually goes to agro-processing units, agro-trading and related businesses, while primary farming is shunned (Jessop et al. 2012).

Table 1

Commercial banks' lending to agriculture in Namibia between the years 2001 until the $1^{\text {st }}$ quarter of 2015

\begin{tabular}{|c|c|c|c|c|c|c|c|}
\hline \multirow[b]{2}{*}{ Years } & \multicolumn{7}{|c|}{ Sectors } \\
\hline & Agriculture & Fishing & $\begin{array}{l}\text { Mining and } \\
\text { quarrying }\end{array}$ & Manufacturing & $\begin{array}{l}\text { Building and } \\
\text { construction }\end{array}$ & $\begin{array}{c}\text { Commercial } \\
\text { \& services }\end{array}$ & $\begin{array}{l}\text { Resident } \\
\text { sectors and } \\
\text { others }\end{array}$ \\
\hline 2001 & 1769.47 & 1669.90 & 307.27 & 2151.34 & 1632.7 & 11371.98 & 19008.97 \\
\hline 2002 & 1730.07 & 1945.86 & 377.8 & 2109.92 & 2125.38 & 12261.11 & 20297.97 \\
\hline 2003 & 2294.08 & 2933.89 & 929.55 & 2230.59 & 3223.53 & 15067.91 & 29785.47 \\
\hline 2004 & 2383.30 & 2759.2 & 1322.91 & 1557.73 & 5236.32 & 18363.03 & 37926.55 \\
\hline 2005 & 2975.46 & 3753.03 & 1618.73 & 1629.68 & 1718.51 & 20472.57 & 46769.23 \\
\hline 2006 & 3109.53 & 2723.15 & 1043.86 & 1694.45 & 1308.12 & 30773.68 & 44673.74 \\
\hline 2007 & 3657.50 & 2416.1 & 1633.06 & 1995.33 & 1351.11 & 33404.42 & 64079.84 \\
\hline 2008 & 4580.98 & 3011.7 & 2011.37 & 2648.12 & 1770.02 & 36163.22 & 70565.23 \\
\hline 2009 & 5704.75 & 3090.91 & 3010.35 & 2800.24 & 1918.79 & 40152.29 & 76131.27 \\
\hline 2010 & 6560.92 & 3664.09 & 2266.73 & 2455.92 & 2157.93 & 45271.85 & 80328.68 \\
\hline 2011 & 7219.88 & 3492.93 & 2266.73 & 3030.29 & 2539.73 & 51795.87 & 91987.06 \\
\hline 2012 & 9071.36 & 3928.23 & 3658.21 & 3382.67 & 2373.15 & 62552.29 & 102836.27 \\
\hline 2013 & 10768.13 & 3330.25 & 5223.74 & 4066.88 & 3547.02 & 70127.1 & 119304.86 \\
\hline 2014 & 13352.49 & 3473.7 & 5223.25 & 4391.13 & 4317.85 & 81924.46 & 139349.67 \\
\hline $\begin{array}{l}2015\left(1^{\text {st }}\right. \\
\text { Quarter) }\end{array}$ & 3576.41 & 909.86 & 1392.09 & 1337.89 & 1466.94 & 23047.61 & 36622.01 \\
\hline Total & 78754.33 & 43102.8 & 32285.65 & 37482.18 & 36687.1 & 552749.39 & 979666.82 \\
\hline
\end{tabular}

Source: Abiatar (2015)

Despite the existence of and lending by commercial banks, the Bank of Namibia (2013) reports that commercial banks in Namibia have been operating inefficiently, because, according to the bank-cost efficiency ratio, they are above 50 percent which is not desirable. This inefficiency could be a result of the domination of the industry by the four main banks and thus the lack of competition. Ikhide (2000) maintains that attracting new entries to the industry is necessary to 
provide a competitive stimulus and spur innovation in products and practices, including those suitable for the financially excluded.

The 12th Annual Symposium of the Bank of Namibia, held in 2010, on "SME Development in Namibia" argues that, in order to improve access to financial services for the informal sector and bring the poor into the formal banking system, a paradigm shift has to occur. The Bank of Namibia argues that mobile wallets have the potential to provide an urgently-needed breakthrough. Banks need to get back to basics and focus on making money through financial intermediation rather than through transaction fees (Bank of Namibia, 2010).

\section{Venture capitalists and private equities}

Venture capital (VC) is explained as an investment made on the basis of the development of a business which is mostly targeted at start-up, green schemes and early stage investments, while Private Equity (PE) focuses on businesses that are already established or going through a stage of changing shareholders. Although there are countries in Africa such as Kenya, Nigeria and South Africa, who are large recipients of VCs and PEs, Namibia is still in its infancy, and investment in businesses comes mainly from local capital. There are 14 Venture capitalists (VCs)/private equities (PEs), according to the Business Financial Solutions report of 2013:i) Stimulus Investments Limited; ii) Spitz Health care investment; iii) First Capital Estate finance fund; iv) Preferred Investment Property fund trust; v) the Desert Stone Fund; vi) OMIGNAM Tunga Real Estate Fund; vii) OMIGNAM Expanded Infrastructure Fund; viii) Tukuneni Capital; ix) The Frontier Property Trust; x) SIM Namibia Real Estate; xi) SME Compete Fund; xii) Namibia Procurement Fund (NamPro Fund); xiii) VPB Namibia Growth Fund; and xiv) the Koigstein Capital Property Investment Fund.

Established in 2004, "Stimulus" was the first and oldest and first private equity fund to be established in the country, investing mainly in well-established companies. After the year 2004, eleven more VCs, PEs, and angel funds were created between 2010 and 2013, which provide different forms of financing, such as trade credit. Although many venture capitals invest in startups, they focus on sectors other than agriculture (see Business Financial Solutions report, 2013).

For the purpose of this research, the concept of financing options includes both monetary and non-monetary options.

\section{$4 \quad$ Methodology}

By using a qualitative methodology approach, a case study research design by way of in-depth semi-structured interview(s) and secondary data sources was used. A structured, as opposed to an unstructured, interview eases the researcher's task of organizing and analysing interview data. It also helps the report's readers to judge the quality of the interviewing method and instruments used (Bowen, 2005:217). The methodology was designed to elicit the financial institutions that are financing agriculture in Namibia, the financing options that farmers are aware of and the reasons for not financing agriculture. Given that the degree to which questions were structured depended on whether an institution financed agriculture or not and whether farmers were aware of other financing options apart from Agribank. It is the participant's knowledge and experience that decided which topics were important in the various interviews (see the interview guides used in Appendix 1). Additional data collection methods were reviews of documents from different financial organizations, including international financial reports on the Namibian financial system, as well as green-scheme project documents that were analysed for this study.

\section{Sample and site selection}

Purposive (judgement) sampling was used for choosing the participants from green-schemes in three research sites in Namibia. The following criteria were included on the demand-side:

- Must be involved in primary production with a farm sized between three and six hectares (ha) for small-scale farmers and between six and 12 ha for medium-scale farmers, as per the 
definition by Agribank.

- Must be producing to sell, and not for family consumption.

The following is the population list of the green-schemes that fit the above criteria which were given to the researcher by the Agricultural Business Development office ${ }^{4}$ (Agribusdev) in Windhoek, Namibia

Table 2

Population list of Green-schemes

\begin{tabular}{|ll|c|l|}
\hline \multicolumn{1}{|c|}{ Green-scheme } & $\begin{array}{c}\text { Number of farmers } \\
\text { (with valid contracts } \\
\text { in a green-scheme }\end{array}$ & \multicolumn{1}{|c|}{ Region } \\
\hline 1. & Etunda green-scheme irrigation project & 9 & Omusati region \\
\hline 2. & Uvhunguhungu green-scheme irrigation project & 10 & Kavango region \\
\hline 3. & Hardap green-scheme irrigation project & 13 & Hardap region \\
\hline 4. & Ndonga-linena green-scheme irrigation project & 28 & Kavango region \\
\hline 5. & Shadikongoro irrigation project & 13 & Kavango region \\
\hline
\end{tabular}

Source: Agricultural Business Development Agency (AGRIBUSDEV), Northern Industry, Windhoek

To gain a clear idea of the location of the green-schemes in the country, see the map below:

Figure 1

Map of Namibia with regions

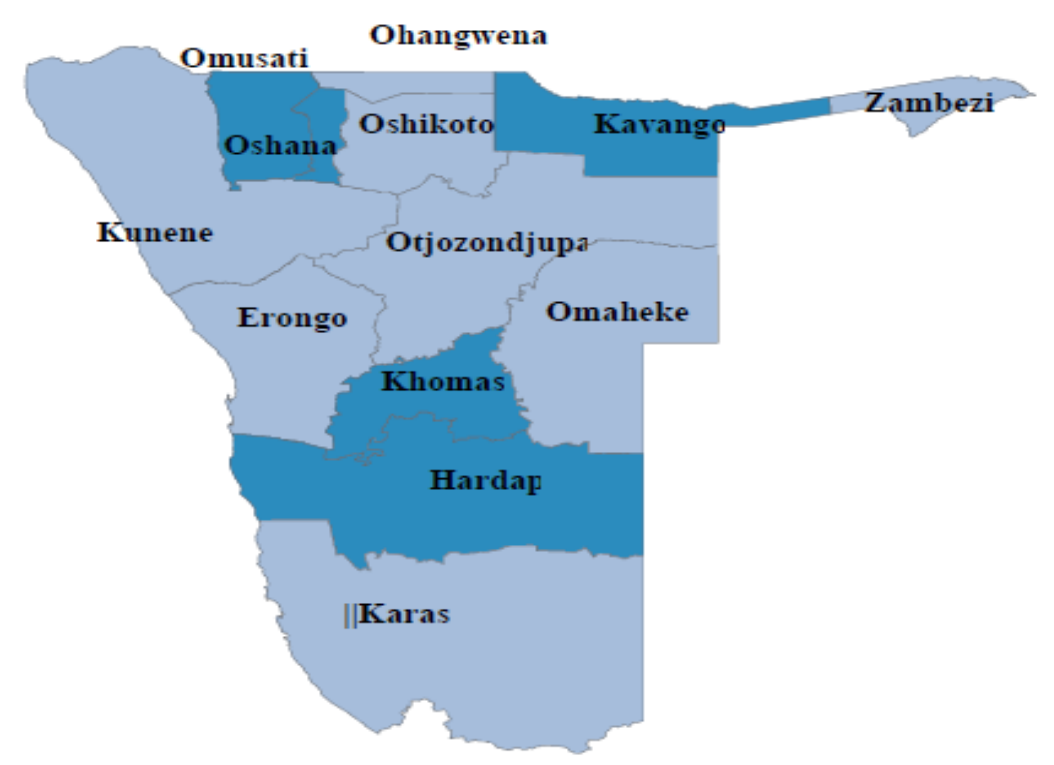

Source: Stat planet ${ }^{60}$

In order to ensure that there was fair representation of the green-schemes in terms of the location of regions in the country and reduce selection bias, one green-scheme was chosen per region. i.e. Etunda green-scheme, Hardap green-scheme and Ndonga linena green-scheme.

Depending on the availability of farmers and a convenient time for the researcher and the participants in various regions, six interviews were held with the Ndonga-linena irrigation scheme, six with the Hardap irrigation green-scheme and six with the Etunda irrigation scheme. In addition, three farms belonging to Agricultural SME owners in Omusati and Kavango who are operating independently outside ${ }^{7}$ the green-schemes were also interviewed. These were Second chance garden in Omusati region, Pozere and Gamade gardens in Kavango region, which resulted in 21 farmers on the demand-side. 
On the supply-side, more than 50 per cent of the banks (all situated in the Khomas region) participated in the study. The criterion used to select the financial institutions was that it had to be a formal institution, that is, a commercial bank, a development bank and venture capital (VC) funds/private equity. The researcher interviewed three of the five commercial banks ${ }^{8}$ (except for Nedbank and Standard Bank, which were too busy to schedule time for an interview), all development banks and four selected VC funds. In order to select VC funds, a brief latest and only study in the country on active local providers of venture capital, private equity and angel funding in Namibia (2013) was used (Business Financial Solutions, 2013). Only VCs, PEs, and Angel funds that targets businesses in "any sector" were interviewed to find out if agricultural SMEs were part of the 'any sector' or not and the reasons for this. These were VPB Namibia growth fund, The Desert Stone Fund, the Namibia Procurement Fund (NPF) and Stimulus Investments. Given the above, the sample on the supply-side resulted in nine formal financial institutions.

All the interviews were conducted after ethics approval by the University of Stellenbosch Business School ethics committee and permission had been granted by the financial institutions.

\section{Justification of the sample size}

Because the emphasis of this research is on quality rather than quantity, the objective was not to maximize numbers but to become "saturated" with information on the topic (see Padgett, 1998: 52). The aim is to capture depth and richness rather than representativeness (see Padgett, 1998: 50). Our interviews have been complemented with secondary information and this has assumed the adequacy of the data. The reason to conduct 21 interviews on the demand-side includes a limited budget, accessibility to the farmers, more especially farmers operating outside the greenscheme projects (where accessibility proved difficult), the willingness of participants to speak freely with the interviewer and data saturation. Furthermore, because of the small population of farmers operating with valid contracts in the various green-schemes on the demand-side (see Table 2 above), a small sample size resulted on the demand-side. Similarly, Koranteng (2010) conducted a similar study in South Africa but interviewed only nine farmers.

\section{Research procedures}

The participants were given informed consent forms to read, ask any questions related to the study and sign the forms before the researcher could commence with the interview. All the questions were translated into Oshiwambo (the language of the Omusati region) and Rukwangari (the language of the Kavango region) for participants who could not understand the official language, English. No language difficulties were experienced in the Hardap region, so all the questions were asked in the official language. One extra person was used to help with translation in the Kavango region, as the researchers could not understand the language. The collected data is reported in such way that persons could not be identified. The interviews lasted no more than 45 minutes each. The interviewing was done during September and December 2014 in the interviewees' places of work, which were located mostly in the green-schemes on the demand-side and bank offices on the supply-side. The interviews were recorded, with the agreement of the interviewees, transcribed for analysis and the anonymity of the participants was ensured.

\section{Data analysis process}

If qualitative research is to bring about meaningful and useful results, it is imperative that the material under scrutiny is analysed in a methodical manner (Attride-Stirling, 2001; Pope, Zeibland \& Mays, 2014). Content and thematic analyses were the main techniques for data analysis. To support the analysis, the software ATLAS.ti was used. For a computer-assisted analysis, Friese (2014) suggests the use of the NCT approach - Noticing things, Collecting things and Thinking about things (see Figure 2).

Noticing things refers to the process of finding interesting things in the data when reading through transcripts, field notes, documents and reports. Collecting things refers to the process of naming things that you have noticed and grouping those that belong together or have the same 
name. This is referred to as coding. This study employed an open coding with an inductive framework approach. Coding refers to categorizing and combing the data for themes, ideas and categories and then marking similar passages of text with a code label (Cooper \& Schindler, 2011). Codes relevant to the research question were created, themes were established and data were systematically examined to see ways in which themes were portrayed.

Thinking about things refers to the ability to consider things that you have noticed and collected in order to find patterns and relations in the data. This is where structuring of the code list began along with the development of categories and sub-categories of codes according to the research question. The categories were refined through repetitive review of the data. During this process sub-categories or new categories were identified and analysis continued until no new categories emerged. The research question memo with a detailed explanation of the research question was then set up and was linked to the various types of financing options categories identified in the data.

The benefits of using the NCT method analysis enables an analyst to work in a systematic manner (Friese, 2014:13-14). The main aim is put all the findings together and gain a coherent understanding of the phenomenon.

Figure 1

The NCT model approach of computer-assisted analysis

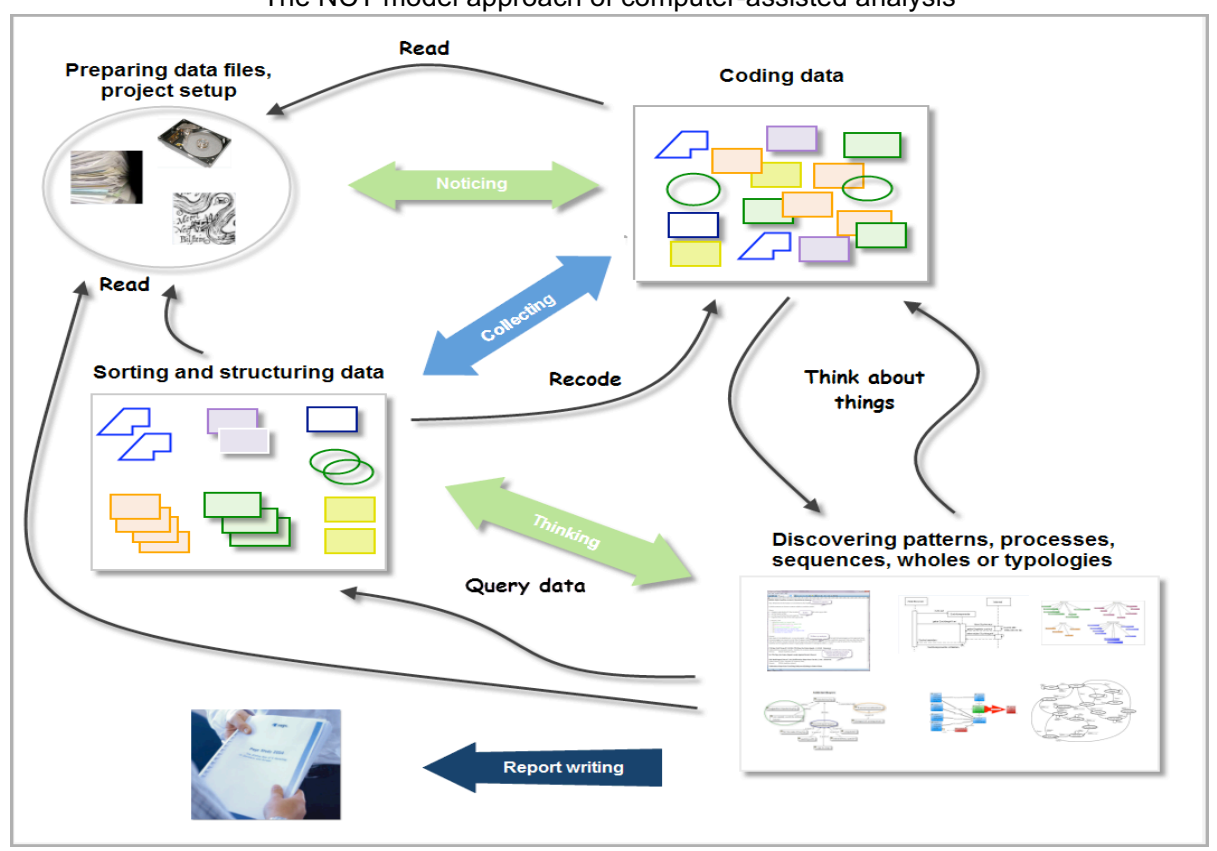

Source: Friese (2014:15)

\section{Limitations of the study}

Methodologically, this paper has few limitations. Because of the small population on both the demand and supply-side and the widely-dispersed country that Namibia is, the sample-size remains small and therefore the number of interviews did not allow for a great variety in answers. Nevertheless, many of the intended participants are representative, because one farmer with an Agribank loan could have represented the entire green-scheme in one region because of repetitions in farmer's interviews, therefore leading to data saturation. In addition, because many of the participants on the demand-side are farmers operating in green-schemes, this may have created some bias. However, green-schemes capture many small- and medium-scale farmers who are the focus of this study. Because of the small sample size, this study may not be generalised to the population but theory generalization may be made. 


\section{Criteria for judging the quality of the research}

According to Yin, 2009:40), there are criteria to consider when judging the quality of the research. These are: construct validity, internal validity, external validity and reliability. For this study, quality was ensured by doing the following:

- For construct validity, multiple sources of evidence i.e. interviews and secondary data sources were used. The secondary data documents provided the information necessary for crossreferencing.

- For external validity, the results of this study may be generalised only to the relevant theory that was used in carrying out the study and not to the population.

The reliability of data for this study is attributable solely to the answers given by the interviewees. A mechanical recording device was used with permission. Procedure on how this study was carried out has been documented to allow collection and analysis by another researcher.

Internal validity is about establishing causal relationships. Because this study did not measure any relationships, internal validity is therefore not suitable.

In the findings section, illustrative comments are documented in quotes for the various themes in order to gain a sense of the financing options provided, the financing options known by farmers and the reasons why formal financial institutions do not provide finance in Namibia.

\section{Results}

Of the nine institutions on the supply-side, there were only three finance agricultural SMEs institutions, which is about 33 percent of the total percentage. These are: The Agricultural Bank of Namibia (Agribank), the Bank Windhoek and the First National Bank (FNB). Agribank is the main institution involved in financing agriculture in the form of loans subsidized by the government. Bank Windhoek finances articles such as tractors for farming, while the FNB performs intermediary on-lending. The rest of the institutions (six institutions out of nine) that formed part of the analysis indicated that they do provide finance but not to agricultural SMEs. Table 2 below provides available data on the number of loans approved and disbursed between the years 2012 and 2014 by Agribank. As much as the number of loan amounts approved is high, loan amounts disbursed are low. This is attributed to unfulfilled collateral requirements and the customer's ability to substantiate his or her repayment ability. Similarly, the loan amounts disbursed kept decreasing because of the drought devastating the country between the years 20122014. Illustrative quotes of specific financing options to agriculture, financing options known to farmers apart from Agribank, and reasons for not financing agriculture from institutions that are not financing farmers are presented in the following section.

Table 2

Data on the financing of Agro SMEs by Agribank ${ }^{9}$

\begin{tabular}{|c|c|c|l|}
\hline $\begin{array}{c}\text { Financial } \\
\text { institution }\end{array}$ & $\begin{array}{c}\text { Loan amounts (N\$) } \\
\text { approved }\end{array}$ & $\begin{array}{c}\text { Loan amounts (N\$) } \\
\text { disbursed }\end{array}$ & \multicolumn{1}{c|}{ Collateral required } \\
\hline & & & $\begin{array}{l}\text { Bonds over farmland, developed/ underdeveloped } \\
\text { municipal plots }\end{array}$ \\
\cline { 4 - 4 } & $2012=271,396,519.62$ & $2012=195,731,015$ & Cession of fixed deposits \\
\cline { 4 - 4 } & $2013=255,720,901.62$ & $2013=245,189,468$ & Cession of surrendering value of policies \\
& $2014=303,544,09.67$ & $2014=244,935,918$ & Listed investments and unit trust investments \\
\cline { 4 - 4 } & & & Suretyships \\
\hline
\end{tabular}

Source: Agricultural Bank of Namibia annual reports 2012, 2013, 2014

'The general purpose of financing by Agribank is to provide reasonably-priced loan financing to our clients, particularly the rural farming community, which would stimulate the growth in the agricultural sector' (Agribank Annual Report, 2011:3) 


\section{Specific funding provided}

Agribank provides various forms of collateralised and subsidised loans (by government) for production to farmers in green-schemes. Farmers who are not in green-schemes also receive assistance in the form of loans, although these are not subsidised by the government. A manager for lending noted:

'Those who have been backed by the government they are being treated differently because we will liaise with the government to provide them the collateral, the ones farming specifically in the green-scheme farm but the others they provide their own collateral'. $(P 18,26: 46)(\text { sic })^{10}$

These loans are disbursed by way of individual lending as opposed to group lending. Although Agribank had tried group lending in previous years, it failed because of poor execution.

We give to individuals; we use to do group loans before. Group loans were not successful because the whole idea then its five, more than ten years ago was that at least the, we wanted to do this group lending so that at least the people in the group give each other pressure in order to service the loans but that was not successful because what happened is that people just met in front of the bank door, form a group in front of the bank door, got the money, they don't even know each other then they shared the money and then everybody disappeared when you go back and to say okay group leader where is that money he will say but I don't even know that guy I just met him in front of the bank door so our experience in terms of that was not quite good, we lost a lot of money and it was one of the initiative that we were trying to do in the communal but it never I think the implementation was a bit wrong in terms of the execution. (P17, 57:60)

As Lehner (2009) points out, group lending may be ineffective when the costs of monitoring for group members are high because of loose social ties, which might have a negative effect on repayment, as the incentive of future credit would no longer count if one member failed to pay.

Apart from Agribank, the FNB performs as intermediary for lending to farmers but only to commercial farmers, because communal farmers do not own any land to serve as collateral. This supports the opinion of Trzeciak-Duval (2003) that the private sector's service tends to target the wealthier sectors.

There is only one scheme that we have, there is a scheme in Okakarara what we call is the Okamakapati. That's Ongombe farmers association what we do is we lend money to the farmer's association and they lend money to the different farmers in their community and they manage the farmer's association or they actually manage that funds on behalf of the bank. We do financing on the basis of security as you know in the communal area there is no, the land doesn't own to someone specific, the security is a problem (P21, 28:52).

Bank Windhoek does not provide monetary finance but it finances the specialised equipment that farmers may need for production but are unable to pay out of their own savings. This requires a higher deposit and it has to be salary-backed.

What we finance for agricultural activities, we finance them with the tractor for example things like equipment' (P19, 32:32). The specialised equipment we ask a higher deposit that can go up to 30 percent. By specialised we mean an equipment that can just be used in that specific industry but not other industries, not like a computer where everybody can use it but just an irrigation system is basically just meant for agriculture so we ask for a higher deposit on that. Reason being if that client did not fulfil the agreement, obviously when we going to repossess and sell not everybody would want to repossess this article. It's likely not to be sold (P19, 81:81).

\section{Financing options known to the farmers}

In order to make a comparison between the existing formal agricultural financing mechanisms and what is actually known to farmers, the latter were asked what financing options they were aware of, apart from Agribank, in order to establish the credit possibilities known to the demand-side. 
Many farmers from all the three regions interviewed (see Figure 3 below) indicated that they were aware only of Agribank.

I looked for assistance from Agribank because there is nowhere else one can get money doing such type of work and in such a place'. (P16, 105:105). Another participant noted: When it comes banks I only know of Agribank. (P13, 95:95)

Medium-scale farmers (all from the Hardap irrigation green-scheme) pointed to commercial banks (although they complained about the interest rates) and village councils, while others, especially independent farmers, felt that there was a lack of information in the country on the different financing options available.

I am not aware of any but those are the type of things we would like to get information on.

There is lack of access to information because you hear of people who have been given kind of assistance apart from loans but I don't know how that happens (P16, 98:98).

The lack of information is consistent with the results found by Abor and Biekpe (2006). They report that, although there are many funded schemes available to SMEs, they are mostly underutilized because firms are sometimes not aware of these non-bank financing options and therefore rely heavily on the inadequate and collateral-driven bank finance. Similarly, De Klerk, Fraser and Fullerton (2013) maintain that familiarity with formal financial products is limited, as is farmers' awareness of the formal sources of help.

Figure 3

Financing options known by farmers in various regions ${ }^{11}$

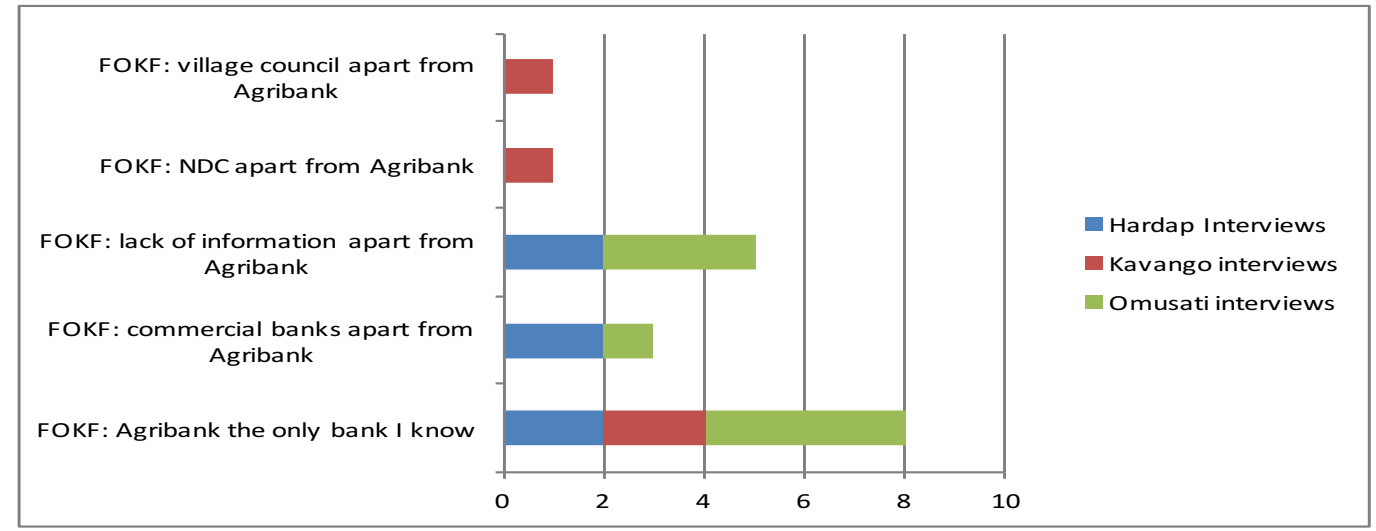

Source: Author's data, software used: ATLAS.ti and Microsoft excel

\section{Reasons for not financing agriculture}

Formal lenders in Namibia cite the lack of expertise and high risk in financing agriculture as the main reasons for not financing agriculture (see Figure 4 below).

Coates and Hofmeister (2012) point out that the understanding by potential investors is limited when it comes to businesses in the agricultural sector. This is confirmed in the findings of this paper because all the Venture Capital funds acknowledged the lack of expertise as one of the main reason for not taking the route of financing agriculture.

The reason for not financing the agricultural industry one is just the nature of the industry itself being agriculture you need to have specialist people that have specialised in that industry and who will be able to analyse the applications in that industry you know in the right way (P19, 28:28).

Another Venture Capitalist respondent noted: We would have loved to go into farming for instance or agriculture but we just said no, look here, we know nothing about agriculture (P29, 27:27). It is important to note that, although Bank Windhoek may assist in purchasing agricultural production 
machinery such as tractors and machines, these are treated as normal transactions only for people who can provide proof of income in order for the bank to determine repayment possibility.

Figure 4

Reasons for not financing agriculture from financial institutions ${ }^{12}$

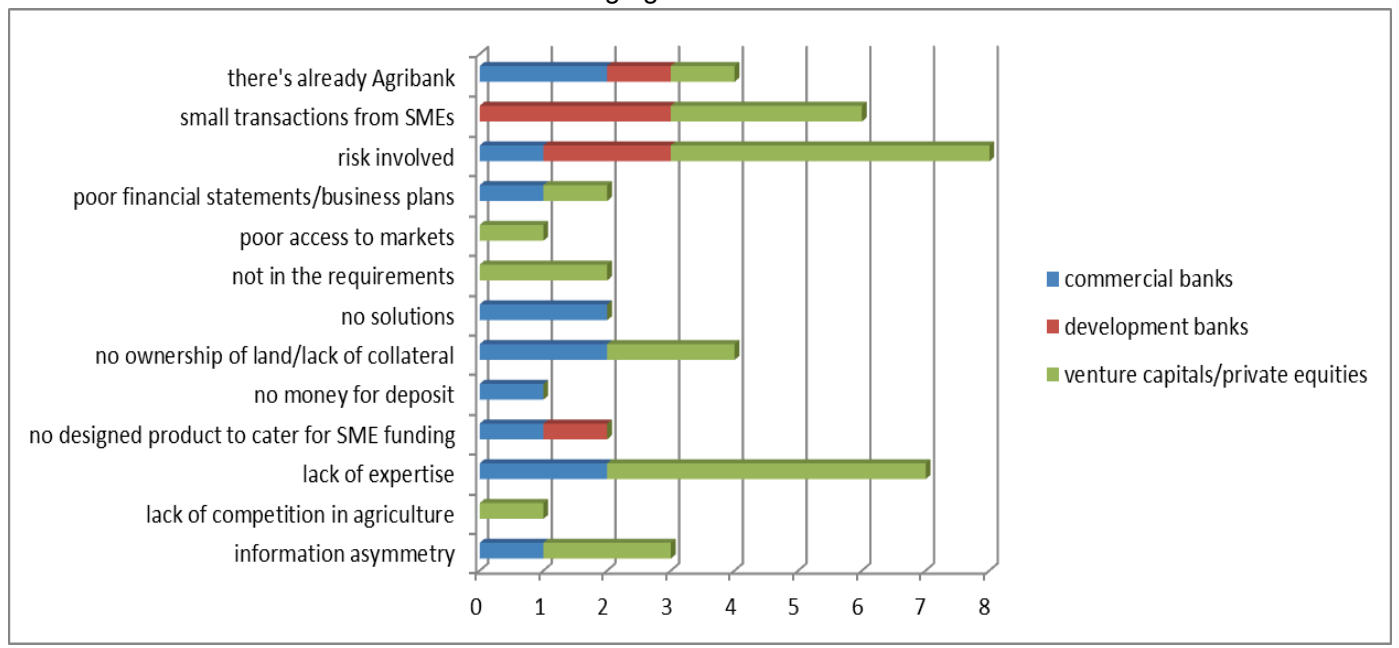

Source: Author's data, software used: ATLAS.ti and Microsoft excel

Furthermore, risk involved in financing agriculture also scored highest among the reasons found for not financing agricultural SMEs. This is consistent with results found by the World Bank (2008b) that, because of reasons ranging from the weather to the low-returns in agriculture, SMEs, particularly farmers in primary production, are perceived to be high-risk businesses, as opposed to farmers adding value to an already-produced product.

Being able to tell us what the risk involved is, you know the potential of that business and etcetera etcetera. For example, if the person would want to do cropping, you know it is one of the things that is viewed to be higher risk because the reason is you don't really know would this person be able to harvest or their project to harvest, What in case probably some natural disasters you know, diseases that you know can arise in the middle of you know, the process and all those things. (P19, 32:32)

Risks prevalent in the agricultural sector due to dependencies on nature, potentially capital intensive nature of agriculture with limited return capacity, unless the intensity is increased on the back of possible technological advances that comes at great cost as well. (P24, 47:47).

As for the Development Bank of Namibia, they argue that Agribank is already there, so they do not perceive the need to finance agriculture.

Agribank by law and by it's pure definition is supposed to look at the agri-side of things were we look at the more commercial side of things so that distinction is there and that's why most of that products if not all will be routed through Agribank (P20:47:47).

Nigeria has found that the high administrative or transaction costs of lending and investment of small amounts discourage financial institutions from investing in agriculture (Abereijo \& Fayomi, 2005, as cited in Akingunola, 2011). This is also the case in Namibia, which is a major concern coming specifically from development banks and venture capital funds.

\section{Discussion and implications}

The aim of the study was to investigate the financing options for agricultural SMEs from both the demand and the supply-perspectives and the reasons for not financing agriculture. Findings endorse that, on the supply-side, although financial institutions exist, very few (three out of nine) 
are interested in financing or providing support for agriculture to small and medium-scale farmers which by implication means that there is a lack of financial resources for agricultural production in the country. This implies that financial penetration in the country is low when it comes to agricultural financing. This is disturbing, as Trzeciak-Duval (2003) cautions that government should ensure competition in financial markets in order to drive innovation and efficiency and minimise the risk of monopolistic practices.

Although the agricultural sector is rated as the third highest sector to which commercial banks in Namibia lend, as shown in Table 1, it could be that this lending is mostly to large and wellestablished farmers with collateral. This assumption is based on the fact that, of the commercial banks interviewed in this study, the FNB finances only SMEs with title to land and in commercial areas.

We do financing on the basis of security as you know in the communal area there is no, the land doesn't own to someone specific, the security is a problem.

Bank Windhoek finances farmers' equipment, but this has to be salary-backed. The reality, however, is that the majority of agricultural SMEs, particularly those in green-schemes, are not farming in commercial areas and do not have title to land, indicating a challenge to access to finance for farmers without collateral.

All the venture capitals interviewed during this study acknowledged that they had no expertise for financing SMEs in agriculture: 'the reason for not financing the agricultural industry one is just the nature of the industry itself being agriculture you need to have specialist people. This finding resonates with the argument by Siebel et al. (2005), who maintain that the belief held by bank Chief Executive Officer(s) and donors with unsurmountable problems of agricultural finance has turned into a self-fulfilling prophecy, either by categorically excluding this type of finance, or, when giving it a try, failing because loan officers are not experienced and not convinced. Narteh (2013) suggests that there is a need for banks to monitor and understand the business needs of the SMEs and provide adequate finance to ensure effective business development. It would also be prudent for the banks to segment the SMEs according to specific sectors so that the bank staff could specialise and provide the necessary services as required.

Further, the negative bias of financial institutions in perceiving Agricultural Small- and Medium- Scale Enterprises to be high risk presents as fear on the part of financial institutions to become innovative and manage their risks, while the failure of group lending by Agribank appears to be because of poor planning. The perception of risk might be linked to fears of crop failure, because agriculture is largely rain-dependent and drought results in uncertainty for the financial institutions as to whether these businesses will able to harvest. However, risks can always be mitigated. For example in Malaysia, the establishment of the SME Bank, with added corporate advisory functions and consultation given by coach clients, was an attempt by Malaysia to correct the risk profile of the SME borrowers (Ramlee \& Berma, 2013). There are also promising signs in Kenya and Ghana of greater agricultural finance by increasing capacity-building for staff in banking institutions. Given the right circumstances, the model used in these countries could work in other African countries, including Namibia (Coates \& Hofmeister, 2012:87). According to Hartig et al. (2014:172), there has been no empirical evidence in the literature to prove that indeed lending to agriculture is more risky than lending to other sectors. They note that it is often misleading to state that banks assess risk of farming businesses and lending to agriculture as high risk. Unfortunately many banks and other financial institutions have no clear understanding about farm economics and market for agricultural produce and they are lacking appropriate approaches to analyzing the related risks so there is actually no base for a professional credit risk assessment by the banks. Thus, the reference to high risks in agriculture by banks is often only uniformed perception based on prejudices.

According to Cabannes (2012), agricultural planners often fail because farmers are not kept well informed, which also explains the reluctance on the part of SMEs to ask for loans. In this paper, insufficient information about the few credit possibilities available for farmers, especially 
those employed outside the green-schemes, demonstrates poor marketing from financial institutions. This goes to show that information is not only relevant to lenders to make informed decisions as to whom they should lend, but also to borrowers to seek financial assistance. Firms stay with the same bank not simply because the bank treats them well but because that bank has information available (Sharpe, 1990:1070).

It is safe to say that, information asymmetry, lack of expertise, small transaction from SMEs and the risks involved do play a major role in fulfilling the loan demand.

\section{Conclusions}

The findings of this paper confirm and expand on previous studies and can be summarised as follows: the financing of agriculture is a major bottleneck in expanding agricultural production. Financial resources are lacking (Siebel et al. 2005) for agricultural small- and medium-scale farmers, particularly those in communal areas. This is rather than an abundance of financial resources. One possible reason why farmers are unaware of any financing options could be that there are so few financial institutions in the country and information on them is not available. Based on other authors cited in this paper, we assert that new financing mechanisms could be achieved by the various types of financial institutions by following the example of experiences in other successful countries.

\section{Endnotes}

1 This information is taken from an unpublished briefing paper prepared by NAMFISA in 2013.

2 Although the definition of Agricultural SME finance includes the entire value chain, Agricultural SME finance in this paper refers to financial services for small and medium enterprises engaged in agricultural crop production (i.e. farming) and not the whole value chain.

3 On the ground, not all farmers employed in the green-schemes have loans.

4 The Agricultural Business Development is an entity responsible for overseeing the operations of the green-schemes in the country, who are financed by Agribank.

5 The researcher only received the population list of farmers from (AGIRBUSDEV) who's farming lease contracts were renewed at the time of interviews. The number of farmers on the ground may be more than reported in this paper.

6 Stat planet is a software for interactive data visualisation and mapping

7 Identified by way of snowball sampling.

8 "Five of the commercial banks" exclude the FIDES bank (see commercial banks' section in the literature view for a full list of these).

9 The data available included small, medium and large farmers.

10 The numbers at the end of the quotations represent the primary document and paragraph numbers. For example P18, 26:46 means that the quotation is from primary document 18, starting in paragraph 26 and ending on paragraph 46 .

11 FOKF in Figure 3 stands for Financing Options Known to Farmers (FOKF).

12 Not all the quotations supporting identified reasons for not financing agriculture in Figure 4 are included in the paper. However, these can be provided by authors on request.

\section{References}

ABIATAR, A. 2015. Bank of Namibia, 16 June. Abiatar.Andreas@bon.com.na.

ABOR, J. \& BIEKPE, N. 2006. Small business financing initiatives in Ghana. Problems and Perspectives in Management, 4(3):69-77.

AGRIBANK. 2011. Agribank annual report 2011. Available at: www.agribank.com.na.

AGRICULTURAL BANK OF NAMIBIA. 2012. Agribank annual report 2012.

AGRICULTURAL BANK OF NAMIBIA. 2013. Agribank annual report 2013.

AGRICULTURAL BANK OF NAMIBIA. 2014. Agribank annual report 2014.

AGRIBANK. 2014. Agribank of Namibia your all season bank. Available at: www.agribank.com.na.

AKINGUNOLA, R.O. 2011. Small and medium scale enterprises and economic growth in Nigeria: An assessment of financing options, small and medium scale enterprises and economic growth in Nigeria: An assessment of financing options. Pakistan Journal of Business and Economic Review, 2(1):77-97.

ALEEM, I. 1990. Imperfect information, screening, and the costs of informal lending: A study of a rural credit market in Pakistan. The World Bank Economic Review, 4(3):329-349. 
ATTRIDE-STIRLING, J. 2001. Thematic networks: An analytic tool for qualitative research. Qualitative Research, 1(3):385-405. Available at: http://qrj.sagepub.com/cgi/doi/10.1177/146879410100100307 [accessed February 2014].

BANK OF NAMIBIA, 2010. $12^{\text {th }}$ Annual Symposium 2010 of the Bank of Namibia - SME Development in Namibia. www.bon.com.na.Bank of Namibia, 2013.

BANK OF NAMIBIA, 2013. Annual Report 2013, Windhoek.

BANK OF NAMIBIA, \& NAMIBIA FINANCIAL INSTITUTIONS SUPERVISORY AUTHORITY. 2015. Namibia Financial Stability Report. Available at: https:/www.bon.com.na/CMSTemplates/Bon/Files/bon. com.na/2f/2f9c905a-517e-497e-ad60-5fe0143775b2.pdf [accessed September 2014].

BESLEY, T. \& COATE, S. 1995. Group lending, repayment incentives and social collateral. Journal of Development Economics, 46:1-18.

BHOLE, B. \& OGDEN, S. 2010. Group lending and individual lending with strategic default. Journal of Development Economics, 91(2):348-363. Available at: http://dx.doi.org/10.1016/j.jdeveco.2009.06.004.

BOWEN, G.A. 2005. Preparing a qualitative research-based dissertation: Lessons learned. The Qualitative Report, 10(2):208-222. Available at: http://www.nova.edu/ssss/QR/QR10-2/bowen.pdf [accessed May 2015]. BUSINESS FINANCIAL SOLUTIONS. 2013. Brief study on active local providers of venture capital, private equity and angle funding in Namibia. Available atL http://www.saisprogramme.com/wp-content/ uploads/2014/06/VC-PE-AF-in-Namibia-2014-Final-for-Website-and-Emails.pdf [accessed February 2015]. CABANNES, Y. 2012. Financing urban agriculture. Environment and Urbanization, 24(2):665-683. COATES, M. \& HOFMEISTER, R. 2012. Financing agriculture: Selected approaches for the engagement of commercial finance. In T. Beck \& S.M. Maimbo (eds.) Financial sector development in Africa: Opportunities and challenges. Washington: Washington DC: World Bank:83-108. Available at: http://dx.doi.org/10.1596/9780821396285_CH03.

COOPER, D.R. \& SCHINDLER, P.S. 2011. Business research methods ( $3^{\text {rd }}$ ed.) N. Jacobs, K. Harlow, \& J. Bishop (eds.). Berkshire: McGraw-Hill Education.

DE KLERK, M., FRASER, F. \& FULLERTON, K. 2013. The Status of agricultural and rural finance in South Africa. Available at: www.finmark.org.za/wp.../Rep_statusAgrRurFin_SA_2013_FNL.pdf [accessed February 2015].

DEVELOPMENT BANK OF NAMIBIA. 2014. Annual report. Development Bank of Namibia. Available at:http://www.dbn.com.na/news-reports/annual-reports [accessed June 2015].

FRIESE, S. 2014. Qualitative data analysis with Atlas.ti ( $2^{\text {nd }}$ ed.) K. Metzler (ed.) Washington DC: SAGE. HARTIG, P., JAINZIK, M. \& PFEIFFER, K. 2014. The potential of structured finance to foster agricultural lending in developing countries. In D. Kohn, (ed.) Finance for food-towards new agricultural and rural finance, New York: Springer:295.

HOFF, K. \& STIGLITZ, J.E. 1990. Introduction: Imperfect and rural information credit markets-puzzles and policy perspectives. The World Bank Economic Review, 4(3):235-250.

HUPPI, M. \& FEDER, G. 1990. The role of groups and credit cooperatives in rural lending. World Bank Research Observer, 5(2):187-204.

IKHIDE, S. 2000. Efficiency of commercial banks in Namibia, Occasional paper of the Bank of Namibia, 4. Available at: https://www.bon.com.na/CMSTemplates/Bon/Files/bon.com.na/b8/b8b60638-88ce-457b-a0c2554765376e70.pdf [accessed March 2015].

INTERNATIONAL FINANCE CORPORATION. 2011. Scaling up access to finance for agricultural SMEs policy review and recommendations. Available at: http://www.gpfi.org/sites/default/files/documents/ G20_Agrifinance_Report (FINAL ONLINE).pdf [accessed July 2014].

INTERNATIONAL MONETARY FUND. 2007. Namibia: Financial system stability assessment, including report on the observance of standards and codes on banking supervision. Available at: http://www.imf.org/ external/pubs/ft/scr/2007/cr0783.pdf [accessed April 2014].

JAYASINGHE, U.K. 2009. Applied study on local finance for urban and peri-urban producers - Gampaha. Available at: http://www.ruaf.org/sites/default/files/Local finance for urban and peri-urban producers in Gampaha Sri Lanka.pdf [accessed June 2014].

JENSEN, F.E. 2000. The farm credit system as a government-sponsored enterprise. Review of Agricultural Economics, 22(2):326-35. Available at: http://www.blackwellpublishing.com/journal.asp?ref=1058-7195 [accessed July 2014]. 
JESSOP, R., BOUBACAR D., MARJAN, D., ABDALLAH, M., JOB, H. \& BERT, V.M. 2012. Creating access to agricultural finance creating access: Based on a horizontal study of Cambodia, Mali, Senegal, Tanzania, Thailand and Tunisia. Available at: http://reherche/afd.fr [accessed January 2014].

KAAKUNGA, E., ZAARUKA, P.B., MOTINGA, E. \& STEYTLER, J. 2004. Viability of commercial bank branches in rural communities in Namibia. BoN Occassional Paper OP-2/2004. Available at: https://www.bon.com.na/CMSTemplates/Bon/Files/bon.com.na/4f/4f282f2c-686b-42c1-8b6b7dabd2b8100d.pdf [accessed December 2015].

KLEIN, B., MEYER, R., HANNIG, A., BURNETT, J. \& FIEBIG, M. 1999. Better practices in agricultural lending. Food and Agriculture Organization.

KODONGO, O. \& KENDI, L.G. 2013. Individual lending versus group lending: An evaluation with Kenya's microfinance data. Review of Development Finance, 3(2):99-108. Available at: http://linkinghub.elsevier. com/retrieve/pii/S1879933713000158 [accessed July 2014].

KORANTENG, K.Y. 2010. Contract farming model of financing smallholder farmers in South Africa: The case of the IDC-KAT river citrus development scheme. Unpublished Master's thesis, Stellenbosch University.

LEHNER, M. 2009. Group lending versus individual lending in microfinance. SRB/TR 15 Discussion Paper, No.299. Available at: http://nbn-resolving.de/urn:nbn:de:bvb:19-epub-13255-5 [accessed June 2015].

MENGES, W. 2015. The Namibian - Govt to spend billions on SOEs. The Namibian. Available at: http://www.namibian.com.na/indexx.php?id=25264\&page_type=story_detail [accessed April 2015]. MINISTRY OF AGRICULTURE WATER AND FORESTRY. 2008. Green scheme policy. Windhoek. MOLLETT, J.A. 1984. Planning for agricultural development. New York: St. Martin's Press.

NAMIBIA TRAINING AUTHORITY. 2013. Sector skills plan. Windhoek. Available at: http://nta.com.na/wp-content/uploads/2013/07/SECTOR-SKILLS-PLAN-FOR-THE-AGRICULTURALSECTOR-2013-2017.pdf [accessed May 2015].

NARTEH, B. 2013. SME bank selection and patronage behaviour in the Ghanaian banking industry. Management Research Review, 36(11):1061-1080. Available at:

http://search.proquest.com/docview/1447819156?accountid=14495\nhttp://diana.uca.es:4550/resserv?genre=a rticle $\&$ issn $=20408269 \&$ title $=$ Management + Research + Review $\&$ volume $=36 \&$ issue $=11 \&$ date $=2013-11-$ $01 \&$ atitle $=$ SME+bank+selection + and + patronage+behaviour+in+the+Ghanai [accessed May 2015].

NDJOZE, J. 2012. Agribank speaks challenges. The Villager Newspaper. Available at: http://www.thevillager.com.na/articles/1055/Agribank-speaks-challenges/ [accessed June 2015]. NORTON, G.W., ALWANG, J. \& MASTERS, W.A. 2015. Economics of agricultural development: World food systems and resource use ( $3^{\text {rd }}$ ed.) Routledge.

OBENG, S.K. 2008. Rural banking in Ghana: It's impact on rural farmers (A case study of Abokobi rural area). Samven's Research and Consultancy Unit:4. Available at: http://cdn.modernghana.com/images/ content/report_content/RURAL\%20BANKING\%20IN\%20GHANA\%20ITS\%20IMPACT\%200N\%20RUR AL\%20FARMERS.pdf [accessed January 2015].

OLUTUNLA, G.T. \& OBAMUYI, T.M. 2008. An empirical analysis of factors associated with the profitability of small and medium - enterprises in Nigeria. African Journal of Business Management (November):195-200.

PADGETT, D.K. 1998. Qualitative methods in social work research: Challenges and rewards. J. Nageotte \& F. Lyons (eds.) Thousand Oaks, CA: Sage publications.

POPE, C., ZIEBLAND, S. \& Mays, N. 2014. Qualitative research in health care. Analysing Qualitative Data, 320(7227):114-116.

RAMLEE, S. \& BERMA, B. 2013. Financing gap in Malaysian small-medium enterprises: A supply-side perspective. South African Journal of Economics and Management Sciences, 16(16):115-126.

SAMSEL, L.A., HAMBLEY, D.I. \& MARQUARDT, R.A. 1991. Agribusiness' competitiveness for venture capital. Agribusiness, 7(4):401-413.

Samuel, Y., Ernest, K. \& Awuah, J.B. 2012. What are small enterprises finance needs? European Journal of Business and Management, 4(17):196-207.

SCHUTTE, T. 2015. The forgotten farm worker, Namibia. Available at: http://www.namibian.com.na/ indexx.php?id=24809\&page_type=story_detail [accessed April 2015]. 
SEIBEL, H.D., GIEHLER, T. \& KARDUCK, S. 2005. Reforming agricultural development banks reforming agricultural development banks. Available at: http://www.gtz.de [accessed April 2015].

SHARPE, S. 1990. Asymmetric information, bank lending and implicit contracts: A stylized model of customer relationships. The Journal of Finance, 45(4):1069-1087. Available at: http://www.jstor.org/ stable/2328715 [accessed April 2015].

TONIN, C., DIECI, P., RICOVERI, A., FORESI, S. \& HANSOHM, D. 1998. Financial services for small enterprises in Namibia. Joint Consultative Committee. Windhoek.

TRIVELLI, C. \& VENERO, H. 2007. Agricultural development banking: Lessons from Latin America? Instituto de Estudios Peruanos

TRZECIAK-DUVAL, A. 2003. Agriculture finance and credit infrastructure - conditions, policies and channels. Agric. Econ, 49(3):106-112.

WORLD BANK. 2008a. Increasing access to rural finance in Bangladesh: The forgotten missing middle. The World Bank. Available at: doi:10.1596/978-0-8213-7333-0.

WORLD BANK. 2008b. World Development Report 2008: Agriculture for Development. 54. The World Bank. Available at: doi:10.1596/978-0-8213-7233-3.

YIN, R. 2009. Case study research: Design and methods ( $5^{\text {th }}$ ed.) SAGE publications. Available at: http://books.google.com/books?hl=en\&lr=\&id=FzawIAdilHkC\&oi=fnd\&pg=PR1\&dq=Case+Study+Researc $\mathrm{h}+$ Design+and+Methods\&ots=1X6R7goWYv\&sig=ZgXTX0AHOMZCW1UoGEsHJ0FvDKU [accessed March 2014].

\section{Appendix 1}

Interview guide for Agribank and other relevant stakeholders

\section{Introduction}

\section{Personal Experience level}

1 Name of financial institution.

2 What position do you hold in the Department?

Financing constraints, options and existing support mechanisms (Agribank and other relevant stakeholders)

1 What kind of borrowers do you deal with? (Small, Medium, Large -scale Enterprises)

2 Which of the categories of borrowers above do you prefer and why?

3 Do you fund agricultural SMEs involved in primary production? If not, why? (please elaborate.)

The following questions were applicable only if the institution is involved in financing or providing support to agricultural SMEs

4 What other support/services do you offer to primary agricultural SMEs, apart from providing funds, etc.?

5 What are the lending criteria used in terms of providing financial access or any support to primary agricultural SMEs?

6 What problems can you can identify when agricultural SMEs apply for finance or assistance?

7 What support do you provide to assist SMEs in overcoming the problems experienced when applying for finance?

8 Do you ask for security to grant loans?

9 Why type of security is usually preferred?

Modified from: (Samuel, Ernest, \& Awuah, 2012; Amiss, 2012). Further questions were added arising from the related literature. 


\section{Interview questions for Agro SME clients in Namibia}

\section{Section A - Personal details}

$1 \quad$ Name of business

2 What position do you hold in the business?

3 Do you own a small or medium-scale farm?

\section{Section B-Finance}

$4 \quad$ What was the start-up cost of the business?

5 What was the main source of funds for starting the business?

6 Have you ever applied for a loan from an institution? If yes, where?

7 If you have never applied for a loan from an institution, please explain the reason why you have never applied for one.

(If one answered no in question 6 and gave reason in question 7. The interviewee jumped to question 13 and 14 and that was the end of the questionnaire. If one answered yes in question 6 , we proceeded to question 8 till the end)

8 What were the requirements from your financial provider to get access to finance and what are your thoughts on these requirements?

9 What do you think is/are the biggest challenges to accessing finance for agricultural SMEs in Namibia?

10 Was the loan you applied for approved the first time?

11 What was the amount of the loan that you applied for?

12 If you applied and did NOT receive the loan, what was the reason behind your failure to obtain the loan?

\section{Financial Institutions}

13 Are you aware of AGRIBANK?

14 What are the services that you expect from financial institutions such as AGRIBANK?

15 Which of the following have you approached for advice about access to finance in the past?

16 What other finance options are you aware of?

17 What problems did you experience when you applied for the loan?

18 What was your decision to apply for financial assistance at the institution where you applied?

19 Do you think staff at the financial institution where you applied are knowledgeable enough and understand your business? If NO, please elaborate.

Interview guide adapted from (Samuel, Ernest, \& Awuah, 2012). Further questions were added arising from reading the related literature. 